\title{
PERENCANAAN ARSITEKTUR SISTEM INFORMASI PERGURUAN TINGGI MENGGUNAKAN ENTERPRISE ARCHITECTURE PLANNING
}

\author{
Imay Kurniawan, S.Si \\ Dosen Program Studi Manajemen Informatika \\ Politeknik LP3I Bandung \\ Email : ce6920@gmail.com
}

\begin{abstract}
Abstrak : Pengembangan sistem informasi perguruan tinggi jika dibangun tidak berdasarkan desain dan rancangan yang jelas pada awal pembangunaanya. Akan merusak keharmonisan sistem yang sudah berjalan, jika ada penambahan satu fungsi atau satu sub-sistem pada sistem tersebut. Upaya untuk menghindari terjadinya gangguan keharmonisan sistem dengan melakukan perencanaan arsitektur sistem informasi yang matang sebelum sistem tersebut dibangun.

Dalam penelitian ini penulis menggunakan metodologi Enterprise Architecture Planning (EAP), untuk perencanaan arsitektur sistem informasi perguruan tinggi. EAP menjelaskan arsitektur data, aplikasi, dan teknologi untuk mendukung proses bisnis perguruan tinggi..
\end{abstract}

Kata kunci : Enterprise Architecture Planning, arsitektur data, arsitektur aplikasi, arsitektur teknologi

\section{Pendahuluan}

\section{Latar Belakang Masalah}

Meningkatnya kebutuhan terhadap data dan informasi dalam fungsi bisnis yang dijalankan oleh suatu perguruan tinggi merupakan pendorong pemanfaatan sistem informasi di dalam perguruan tinggi tersebut. Hal ini berdampak pada banyaknya perguruan tinggi yang dalam menerapkan sistem informasi dengan teknologinya hanya dengan memperhatikan kebutuhan sesaat dan penerapan sistem informasi yang saling tumpang tindih. Kondisi tersebut membuat sistem informasi tidak dapat dimanfaatkan sesuai dengan yang diharapkan berdasarkan misi dan tujuan penerapan sistem informasi dalam perguruan tinggi tersebut yaitu efisiensi dan efektifitas dalam pemenuhan kebutuhan perguruan tinggi (Yunis, 2010).

Mengingat pentingnya pengembangan suatu sistem informasi pada suatuperguruan tinggi, maka perguruan tinggi sebagai enterprise pelaksana perlu membuat cetak biru pengembangan sistem informasi sebagai acuan, panduan dan rencana yang jelas bagi pengembangan sistem informasi secara keseluruhan pada perguruan tinggi tersebut.

Dalam penelitian ini, penulis menggunakan metodologi Enterprise Architecture Planning (EAP) yang merupakan proses pendefinisianarsitektur dalam penggunaan informasi untuk mendukung bisnis dan rencana untuk mengimplementasikan arsitektur tersebut. 


\subsection{Rumusan Masalah}

Bagaimana membuat perencaan arsitektur sistem informasi perguruan tinggi?

\subsection{Tujuan Penelitian}

Mengetahui membuat perencanaan arsitektur sistem sistem informasi Perguruan tinggi

\section{Tinjauan Pustaka}

\subsection{Sistem Informasi}

Menurut (Laudon and Laudon ,2004), sistem informasi adalah sekumpulan komponen yang saling berhubungan, mengumpulkan, memproses, menyimpan, dan mendistribusikan informasi untuk menunjang pengambilan keputusan dan pengawasan dalam suatu organisasi.

Sistem informasi dapat didefinisikan sebagai " suatu sistem di dalam suatu organisasi yang merupakan kombinasi dari orang-orang, fasilitas, teknologi, media, prosedur-prosedur dan pengendalian yang ditujukan untuk mendapatkan jalur komunikasi yang penting, memproses tipe rutin tertentu, memberi sinyal kepada manajemen dan yang lainnya terhadap kejadian-kejadian internal dan eksternal yang penting dan menyediakan suatu dasar informasi untuk pengambilan keputusan yang cerdik"(Jogiyanto, 1999).

Sedangkan menurut (Ladjamudin ,2005), sistem informasi dapat didefinisikan sebagai berikut:

1. Suatu sistem yang dibuat oleh manusia yang terdiri dari komponen-komponen dalam organisasi untuk mencapai suatu tujuan yaitu menyajikan informasi.

2. Sekumpulan prosedur organisasi yang pada saat dilaksanakan akan memberikan informasi bagi pengambil keputusan dan atau untuk mengendalikan organisasi.

3. Suatu sistem di dalam suatu organisasi yang mempertemukan kebutuhan pengolahan transaksi, mendukung operasi, bersifat manajerial dan kegiatan strategi dari suatu organisasi dan menyediakan pihak luar tertentu laporanlaporan yang diperlukan.

Dengan demikian dapat disimpulkan bahwa sistem informasi adalah sekumpulan komponen saling berhubungan, mengumpulkan, memproses, menyimpan, dan mendistribusikan informasi dengan tujuan untuk memberi sinyal kepada manajemen dan yang lainnya terhadap kejadian-kejadian internal dan eksternal yang penting dan untuk menunjang pengambilan keputusan, penyajian informasi, pengawasan dan pengendalian di dalam organisasi.

\subsection{Enterprise Architecture Planning}

Enterprise architecture atau lebih dikenal dengan arsitektur enterprise adalah deskripsi dari misi stakeholder yang di dalamnya termasuk informasi, fungsionalitas/kegunaan, lokasi organisasi dan parameter kinerja. Arsitektur enterprise menggambarkan rencana untuk mengembangkan sebuah sistem atau sekumpulan sistem (Spewak, 1992). 
Arsitektur dapat dilihat sebagai cetak biru untuk penempatan optimal dan targetkonforman sumber daya di lingkungan TI untuk mendukung akhir dari fungsi bisnis. Secara khusus, cetak biru tersebut memberikan gambaran garis besar tentang bagaimana elemen (alur, utilitas-baca : platform, jaringan, aplikasi, komponen logis aplikasi) yang cocok, terutama dalam kaitan satu sama lainnya.

Menurut Steven H Spewak, EAP merupakan pendefinisian bisnis dan arsitektur, bukan perancangan bisnis dan arsitekturnya. Arsitektur dalam EAP adalah arsitektur data, aplikasi dan teknologi yang dibutuhkan untuk mendukung bisnis organisasi. Steven H Spewak menyatakan bahwa arsitektur disini dimaksudkan layaknya cetak biru, penggambaran, atau model.

\subsection{Komponen EAP}

Komponen Enterprise Architecture Planning dapat diuraikan dengan metoda dan tools (framework) yang digunakan. Komponen dari EAP menurut Spewak menggunakan dasar dari dua layer dari John Zachman's framework yaitu dari tinjauan planner dan owner. Komponen EAP dapat digambarkan sebagai berikut:

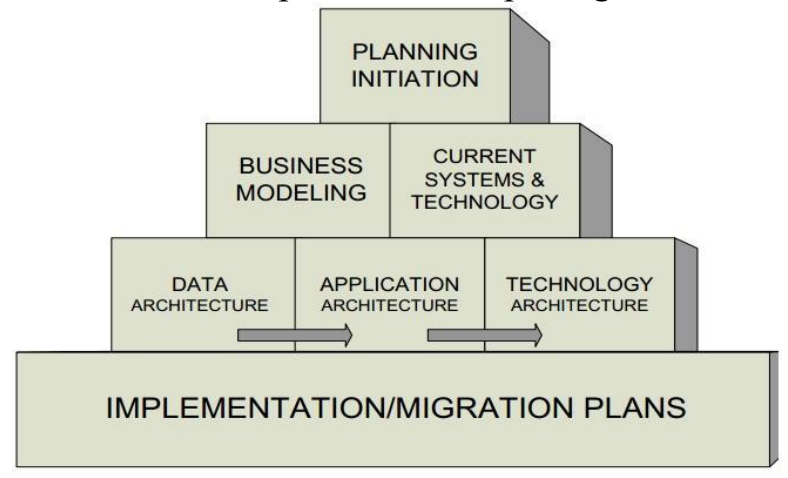

Gambar 2.1. Lapisan Perencanaan Arsitektur Enterprise (Spewak, 1992)

Tahapan -tahapan pengembangan EAP dalam gambar 2 berisikan:

\section{Planning Initiation}

Membahas metodologi dan alat yang digunakan, menentukan siapa saja yang terlibat sehingga dapat menghasilkan rencana kerja EAP dan meminta jaminan komitmen pihak manajemen untuk tahap selanjutnya.

2. Bisnis Modeling

Pengetahuan tentang bisnis dan informasi yang akan digunakan dan proses pendefinisian bisnis enterprise. Tahap ini berelasi dengan strategis bisnis planning yang meliputi 3 aspek yaitu pemahanan terhadap misi, objektif, kebijakan, struktur organisasi, peran dan tanggung jawab setiap orang, serta fungsi dan prosedur yang harus ada.

3. Analisa sistem dan teknologi saat ini Mendokumentasikan dan mendefinisikan semua standar sistem dan teknologi yang digunakan di dalam enterprise, dalam bentuk katalog sumber daya informasi yang merupakan bentuk ringkasan atau rekapitulasi.

4. Arsitektur Data

Arsitektur data adalah proses mengindentifikasi dan mendefinisikan data utama yang mendukung fungsi bisnis yang yang telah didefinisikan dalam model 
bisnis. Dalam arsitektur data terdiri dari entitas data yang mempunyai atribut dan relasi dengan entitas data lainnya. Tahapan pembangunannya yaitu

a. Mendaftar entitas data

Data merupakan pendorong dan langkah utama EAP, sehingga perlu mengidentifikasikan entitas data yang diperlukan dan dihasilkan untuk mendukung bisnis enterprise.

b. Mendefinisikan atribut dan relasi entitas

Membuat standar definisi dan deskripsi untuk setiap entitas dalam arsitektur data dan mengambarkan relasinya. Entitas Relasional Diagram

c. Merelasikan entitas dengan fungsi bisnis

Menentukan entitas data yang dibuat, diambil, diupdate dan dihapus oleh fungsi bisnis dengan membuat matrik entitas ke fungsi bisnis sebagai gambarannya.

\section{Arsitektur Aplikasi}

Arsitektur Aplikasi mendefinisikan aplikasi utama yang diperlukan untuk mengelola data dan mendukung fungsi bisnis dari enterprise. Mengelola data termasuk aktifitas untuk menginput, menganti,menyimpan,mengubah,membuat rangkuman, menganalisis,membuat data referensi. Tahapan pembangunannya, yaitu:

a. Membuat daftar kandidat aplikasi

Mengidentifikasikan seluruh kemungkinan aplikasi yang diperlukan untuk mengelola data dan mendukung bisnis dengan menggunakan matrik fungsi dan entitas data untuk mengukur tingkat kebutuhan aplikasi.

b. Mendefinisikan aplikasi

Menyediakan standar definisi untuk setiap aplikasi yang telah didaftar untuk menghindari fungsi yang ganda.

c. Membuat relasi aplikasi dan fungsi

Mengidentifikasi fungsi bisnis yang secara langsung didukung dan dikelola oleh aplikasi dengan menggunakan matrik fungsi \& aplikasi, matrik unit organisasi \& aplikasi.

d. Membuat analisa dampak ke aplikasi saat

Tahap ini menentukan dampak integrasi aplikasi dengan aplikasi yang sudah ada, yang dapat digunakan pada saat implementasi.

e. Mendistribusikan aplikasi

Tahap ini dilakukan untuk mendapatkan evaluasi dan saran dari pengguna akhir aplikasi dalam unit-unit organisasi

\section{.6. Arsitektur Teknologi}

Mendefinisikan standar teknologi yang diperlukan untuk menyediakan sarana untuk aplikasi yang dapat mengelola dan mendukung fungsi bisnis. Tahapan pembangunannya yaitu:

a. Mengidentifikasikan standar prinsip teknologi yang akan digunakan.

Menentukan jenis standar teknologi yang dibutuhkan enterprise untuk berbagi data dan informasi, contohnya sistem operasi yang portable, scalable, interoperable dan complatible.

b. Mendefinisikan standar teknologi dan distribusi data dan aplikasi, 
Mendefinisikan struktur teknologi dalam menentukan strategi untuk mendefiniskan aplikasi dan data, membuat konfigurasi standar teknologi, mendefinisikan konsep workstation yang akan dibangun.

c. Membuat relasi standar teknologi dengan aplikasi dan fungsi bisnis.

d. Melakukan distribusi arsitekur teknologi

untuk mengkonfirmasi kelayakannya sehingga manajemen enterprise dapat menyetujuinya.

7. Implementasi dan rencana migrasi

Mendefinisikan aturan untuk implementasi aplikasi, penjadwalannya, analisa biaya, serta mengusulkan alur migrasi dari kondisi saat ini ke kondisi yang ingin dicapai.

\subsection{Value ChainMichael E. Porter}

ValueChain Porter adalah model yang digunakan untuk membantu menganalisis aktivitas-aktivitas spesifik yang dapat menciptakan nilai dan keuntungan kompetitif bagi organisasi danfungsi dari value added chain, menurut Michael E. Porter yaitu untuk mendeskripsikan cara melihat bisnis sebagai rantai aktifitas yang mengubah input menjadi output sehingga memiliki nilai bagi pelanggan (Porter, E Michael, 1985).

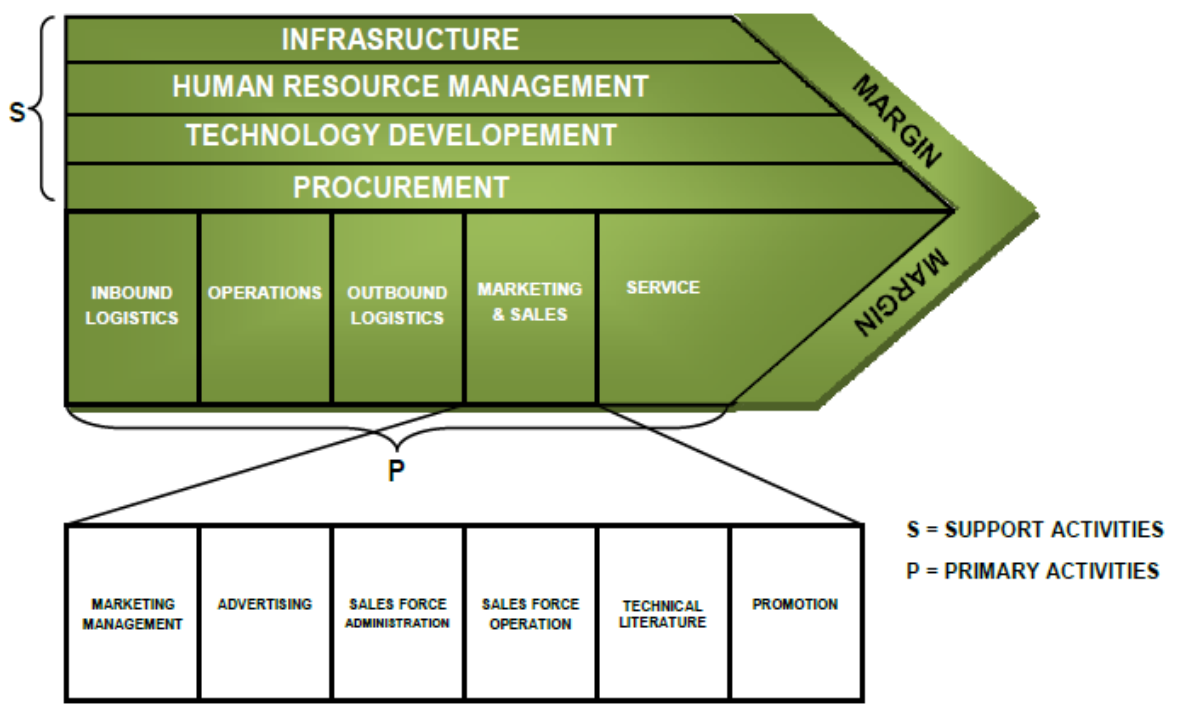

Gambar 2.2 Value added chain Michael E. Porter(Porter, E Michael, 1985)

\section{Perencanaan Arsitektur Sistem Informasi Perguruan Tinggi}

Metodoogi penelitian ini mengaju pada tahapan-tahapan pada struktur EAP, yaitu mulai dari tahap Inisiasi Perencanaan, tahap pemodelan bisnis, sistem dan teknologi. Dari ketiga tahap tersebut di atas akan menghasilkan output arsitektur data, arsitektur aplikasi serta arsitektur teknologi. Tahapan-tahapanya adalah sebagai berikut :

\subsection{Inisiasi Perencanaan}

Dalam fase ini sebenarnya ada tujuh langkah yang harus dikerjakan, yaitu: pendefinisian ruang lingkup dan sasaran pengerjaan EAP, pendefinisian visi, 
pendekatan metodologi perencanaan, pengunaan sumber daya komputer, pembentukan tim perencanaan, persiapan perencanaan kerja EAPdan pengkonfirmasian komitmen manajemen dan pembiayaan. Namun karena ini merupakan tahapan awal, maka analisis difokuskan terhadap kondisi objektif dari organisasi sehingga diperoleh gambaran yang jelas bagi pengembangan arsitektur informasi yang selaras dengan bisnis utama organisasi.

Fokus pada tahapan ini sebagai berikut:

1. Pendefinisian Ruang Lingkup dan Sasaran Pengerjaan

2. Pendefinisian Visi dan Misi

3. Pemilihan Metode Perencanaan

4. Penggunaan Sumber Daya Komputer

\subsection{Pemodelan Bisnis}

Sesuai dengan proses bisnis utama sebagai lembaga penyelenggara pendidikan tinggi maka aktivitas bisnisnya berpedoman pada kegiatan Tridarma Perguruan Tinggi yang merupakan aktivitas inti. Aktivitas inti ini tidak akan berjalan dengan baik apabila tidak didukung oleh aktivitas lainnya seperti manajeman keuangan, manajeman aset, sarana dan prasarana serta manajeman sumber daya manusia.

Untuk mengidentifikasikan area fungsional utama dan pendukung dari perguruan tinggi dapat digambarkan dalam bentuk rantai nilai seperti diilustrasikan pada gambar 3.1. Dalam rantai nilai ini dijabarkan masing-masing aktivitas utama dan aktivitas pendukung perguruan tinggi. Fungsi Bisnis Utama meliputi: Penerimaan Mahasiswa, Operasional Akademik, Pelepasan Akademik serta Penelitian dan Pengabdian Masyarakat.

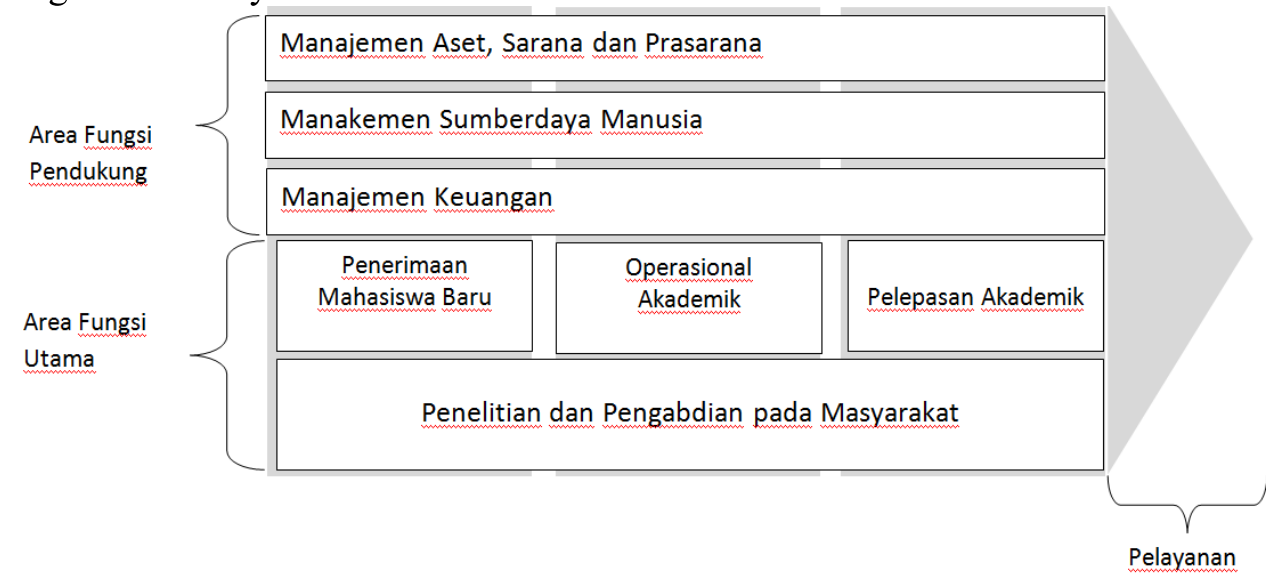

Gambar 3.1

Rantai nilai perguran tinggi sumber (Yunis dan Surendro 2010)

Dalam pemodelan bisnis untuk mendefinisikan fungsi bisnis dapat digambarkan dengan menggunakan Bisnis Process Model Notation. Fungsi bisnis penerimaan mahasiswa baru (gambar 4.2) terdapat 4 aktivitas yang berkaitan dengan proses penerimaan mahasiswa baru diantaranya calon mahasiswa, mahasiswa, administrasi PMB dan program studi. Sedangkan aktivitas sistem meliputi: 
pendaftaran mahasiswa, Seleksi calon mahasiswa, Penetapan mahasiswa baru serta Mahasiswa Baru hasil daftar ulang penetapan mahasiswa.

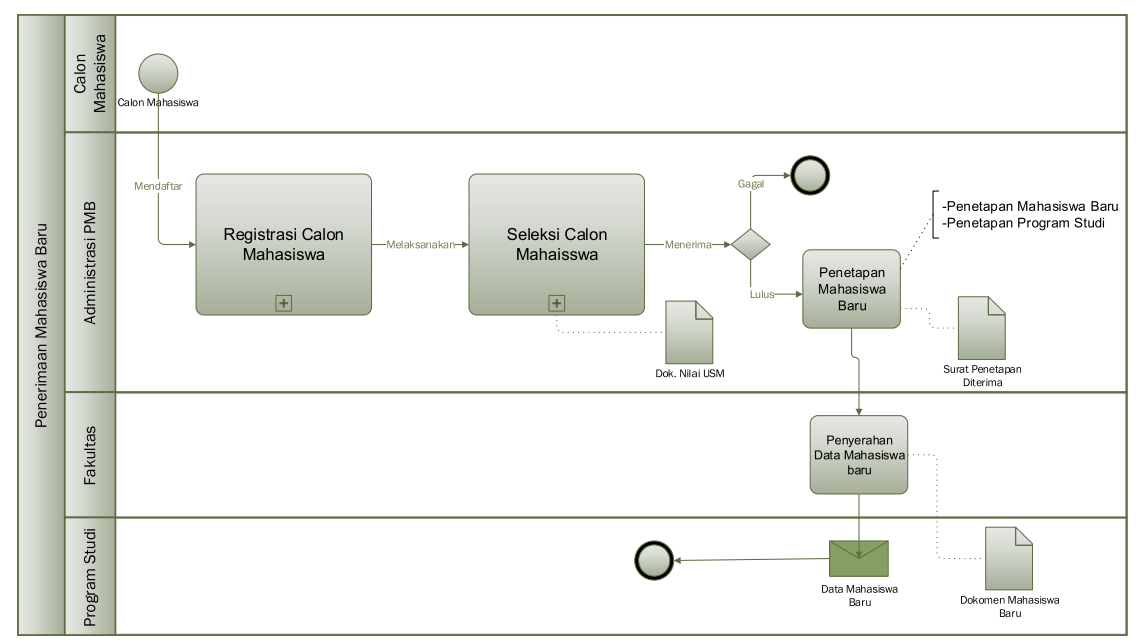

Gambar 3.2

BPMN penerimaan mahasiswa baru

Fungsi bisnis operasional akademik yang masing-masing adalah bagian akademik, mahasiswa dan program studi. Sedangkan aktivitas sistem meliputi: perencanaan operasional akademik, penetapan kurikulum, pendaftaran ulang, perkuliahan, evaluasi, pelaporan akademik serta cuti akademik. digambarkan menggunakan Bisnis Process Model Notation (BPMN) diilustrasikan pada gambar 4.3

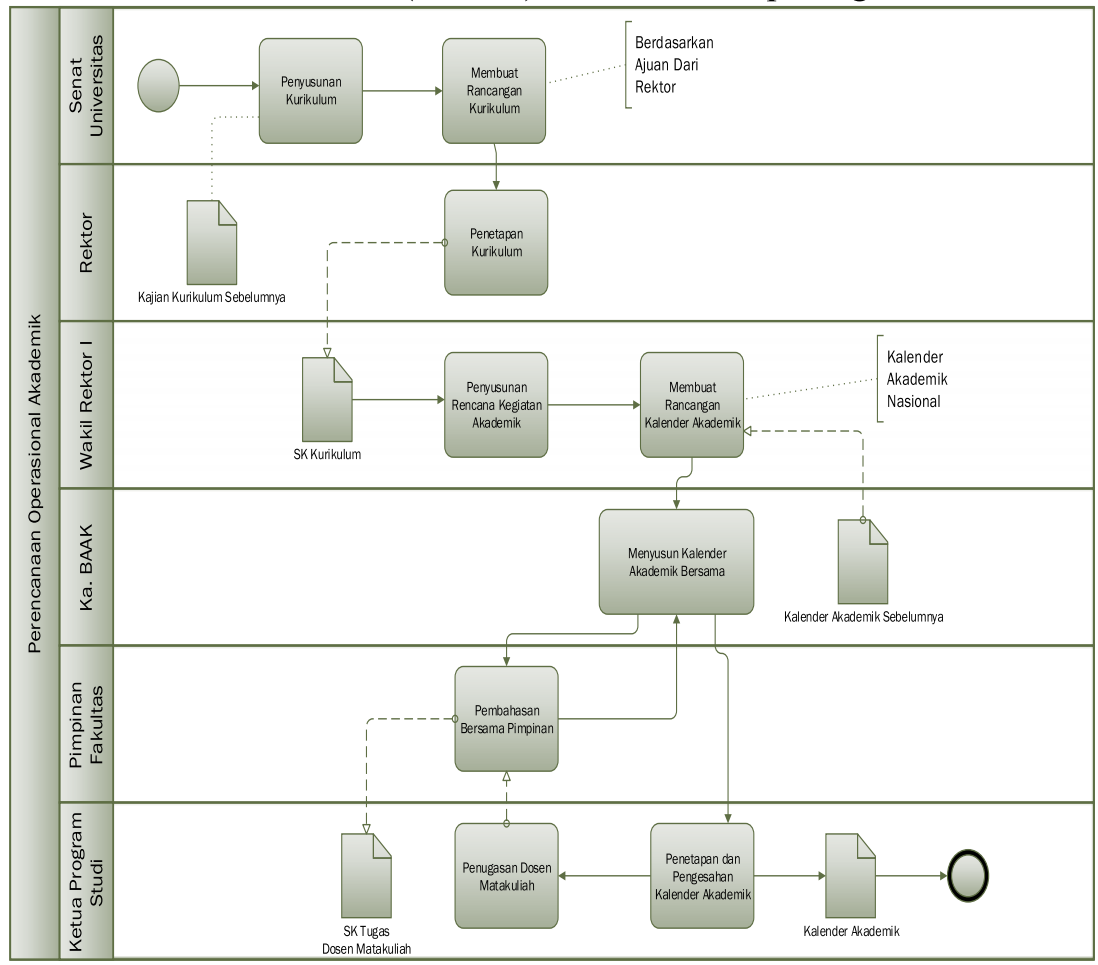

Gambar 3.3

BPMN Perencanaan Operasional Akademik 
Fungsi bisnis pelepasan akademik adalah proses dimana mahasiswa dinyatakan telah menyelesaikan kegiatan akademik sesuai dengan kecukupan jumlah sks tempuh dan masa studi yang telah dicapai, dan merupakan berakhirnya aktivitas akademik pada jenjang tersebut kegiatan ini meliputi : Wisuda, Ijasah dan transkrip nilai. Kegiatan tersebut dapat digambarkan menggunakan Bisnis Process Model Notation (BPMN) pada gambar 4.4.

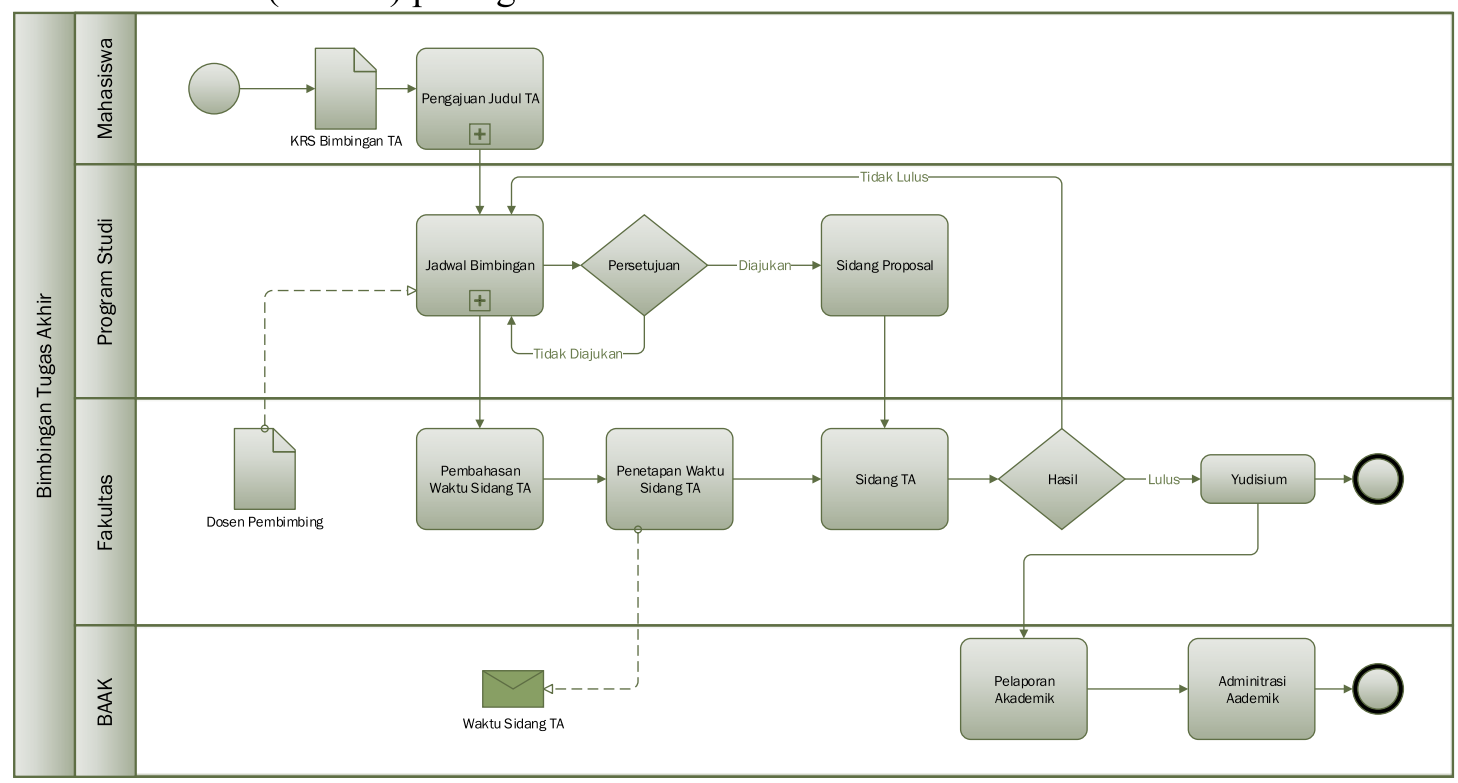

Gambar 3.4

BPMN Pelepasan Akademik

\subsection{Sistem dan Teknologi}

Pada tahap ini akan di dokumentasikan dan di defenisikan seluruh Platform sistem dan teknologi yang dimiliki, digunakan serta dikelolah oleh Perguruan Tinggi. Tahapan ini menghasilkan Information Resource Catalog (IRC) dengan langkahlangkah sebagai berikut:

1. Mempersiapkan koleksi data aplikasi dan teknologi;

2. Mengumpulkan data IRC.

Aplikasi-aplikasi yang terdapat di Perguruan Tinggi terbagi ke dalam tiga bagian: 1. Aplikasi Akademik

Aplikasi ini digunakan untuk mengelola data dari fungsi akademik. Fungsi fungsi yang disediakan oleh aplikasi diantaranya adalah pencatatan dan pengelolaan data mahasiswa, kegiatan belajar mengajar, kegiatan ujian dan pengelolaan nilai.

2. Aplikasi Keuangan

Aplikasi ini digunakan untuk mengelola data dari fungsi keuangan. Fungsi fungsi yang disediakan oleh aplikasi diantaranya adalah pencatatan dan pengelolaan pembayaran biaya pendidikan mahasiswa, pengelolaan kas, pengelolaan piutang serta pembuatan laporan keuangan seperti arus kas dan buku besar. 


\section{Aplikasi Perpustakaan}

Aplikasi ini digunakan untuk mengelola data buku dan bahan bacaan lain yang terdapat pada perpustakaan. Informasi yang ditampilkan adalah daftar bahan bacaan yang terdapat di perpustakaan.

\subsection{Arsitektur Data}

Dalam membuat arsitektur data perlu dilakukan identifikasi data yang mendukung fungsi-fungsi bisnis yang terdefinisi dalam model bisnis. Dalam mendefinisikan arsitektur data yaitu dengan mendaftarkan kandidat entitas data yang ada pada Perguruan Tinggi. Berikut rincian kandidat entitas pada fungsi bisnis utama di Perguruan Tinggi

Table 3.1 Rincian Keterkaitan Area Fungsi Utama dan Entitas Data

\begin{tabular}{|l|l|}
\hline Fungsi Bisnis Utama & \multicolumn{1}{|c|}{ Entitas } \\
\hline Operasional Akademik & Entitas Fakultas \\
& Entitas Program Studi \\
& Entitas Sarana dan Prasarana \\
& Entitas Semester \\
& Entitas Kurikulum \\
& Entitas Kalender Akademik \\
& Entitas Registrasi \\
& Entitas Dosen \\
& Entitas Mahasiswa \\
& Entitas matakuliah \\
& Entitas Jadwal Kuliah \\
& Entitas Presensi Kuliah \\
& Entitas Jadwal Ujian \\
& Entitas Berita Acara \\
& Entitas Nilai \\
& Entitas KHS \\
& Entitas KRS \\
& Entitas Cuti Akademik \\
& Entitas Evaluasi \\
& Entitas Bimbingan TA \\
& Entitas Sidang TA \\
\hline & Entitas Calon Mahasiswa \\
& Entitas Jadwal Ujian \\
& Entitas Pembayaran \\
& Entitas Hasil Ujian \\
& Entitas Administrasi PMB \\
& Entitas Registrasi Calon Mahasiswa \\
& Entitas Mahasiswa Baru \\
\hline & Entitas Mahasiswa \\
& Entitas Fakultas \\
& Entitas Program Studi \\
& Enitas Administrasi Akademik \\
\hline & \\
\hline &
\end{tabular}




\begin{tabular}{|c|l|}
\hline Fungsi Bisnis Utama & \multicolumn{1}{|c|}{ Entitas } \\
\hline & Entitas Akademik \\
& Entitas Transkrip Nilai \\
& Entutas Ijasah \\
& Entitas Alumni \\
\hline & Entitas Dosen \\
& Entitas Mahasiswa \\
Penelitian dan Pengabdian pada & Entitas Judul Penelitian \\
Masyarakat & Entitas Jadwal Seminar \\
& Entitas Program Studi \\
& Entitas Penguji \\
& Entitas Pelaporan \\
\hline
\end{tabular}

Setelah mengidentifikasikan entitas data yang ada kemudian dapat membuat arsitektur data Perguruan Tinggi. Arsitektur data dibuat dengan mengidentifikasikan entitas fungsi bisnis dan entitas organisasi pada saat ini. Arsitektur data ini dapat dipetakan dengan menggunakan ER-diagram.

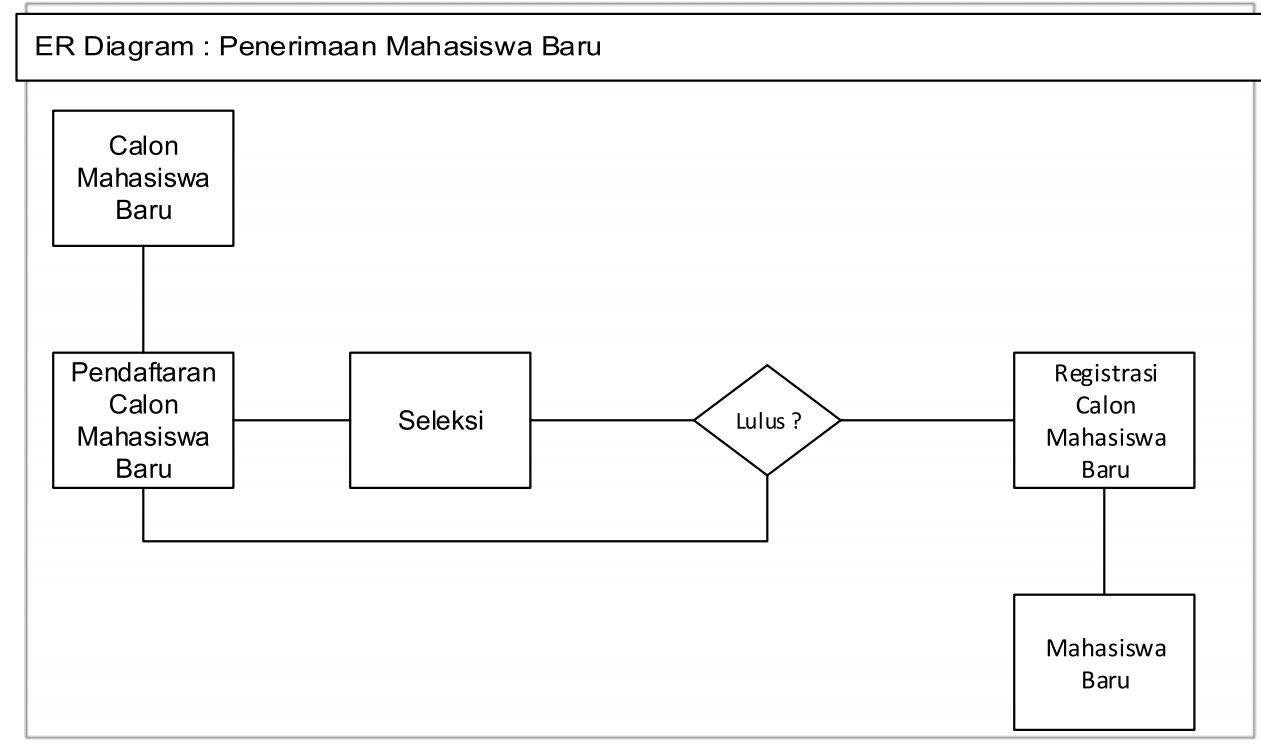

Gambar 3.5

ER Digram Penerimaan Mahasiswa Baru

Gambar. 3.5 menggambarkan diagram model arsitektur data untuk fungsi bisnis penerimaan mahasiswa baru. Entitas calon mahasiswa yang mendaftar, setelah melakukan seleksi ujian dan dinyatakan lulus maka mahasiswa baru melakukan registrasi ulang pada entitas mahasiswa baru. 


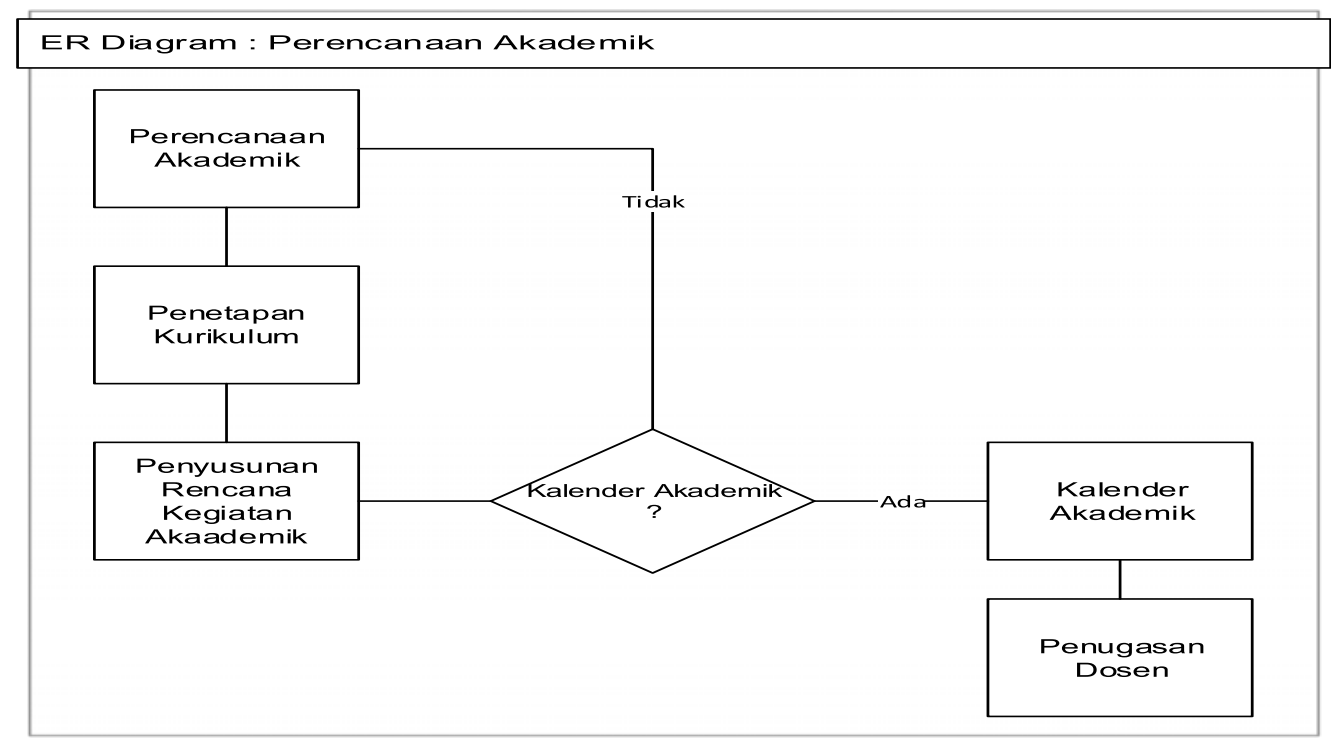

Gambar 3.6

ER Diagram Perencanaan operasional akademik

Gambar 3.6 menggambarkan diagram arsitektur data untuk fungsi bisnis perencanaan Operasional akademik. Entitas fakultas dan entitas program studi melakukan penyusunan rencana kegiatan akademik dan selanjutnya menetapkan kalender akademik dan penugasan dosen matakuliah.

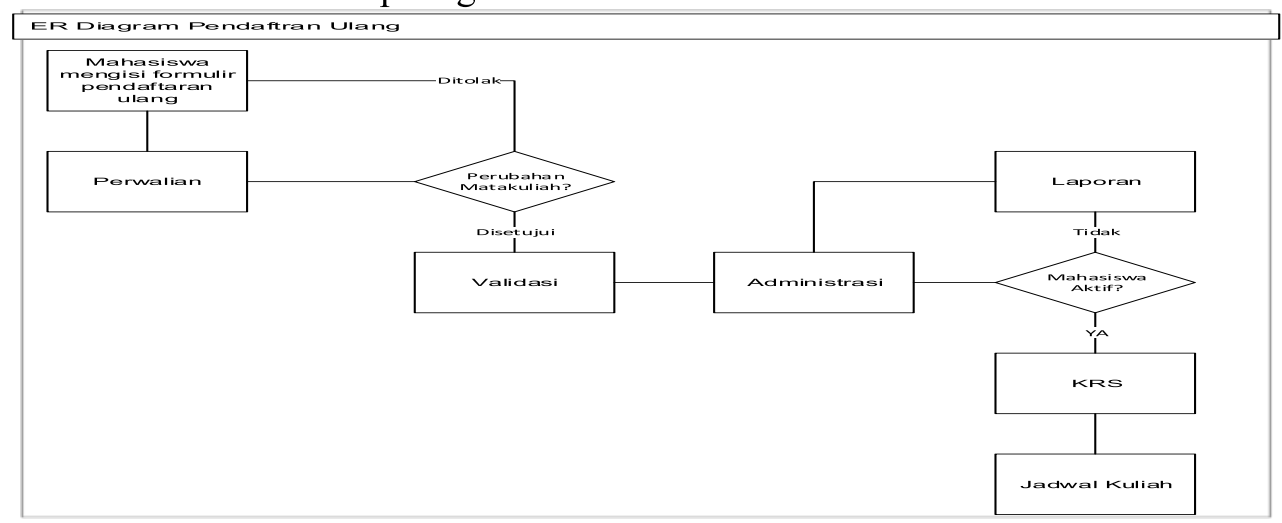

Gambar 3.7

ER Diagram Pendaftaran ulang

Gambar. 3.7 menggambarkan ER Diagram arsitektur data fungsi bisnnis pendaftaran ulang. Pada gambar tersebut digambarkan hubungan entitas mahasiswa, dosen dan adinistrasi akademik, KRS serta jadwal kuliah pada proses pendaftra ulang. 


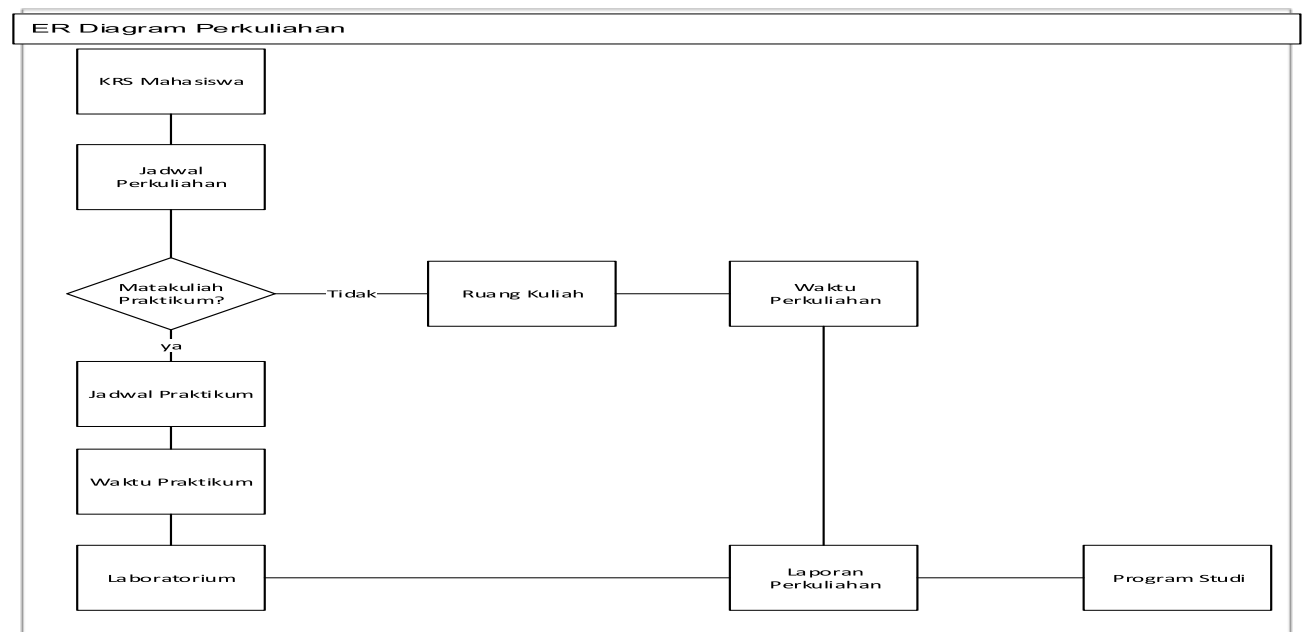

Gambar 3.8

ER Diagram Perkuliahan

Gambar 3.8 menggambarkan arsitektur data untuk aktivitas perkuliahan yang melibatkan mahasiswa jadwal kuliah, jadwal praktikum, ruang kuliah, laporan perkuliahan dan program studi.

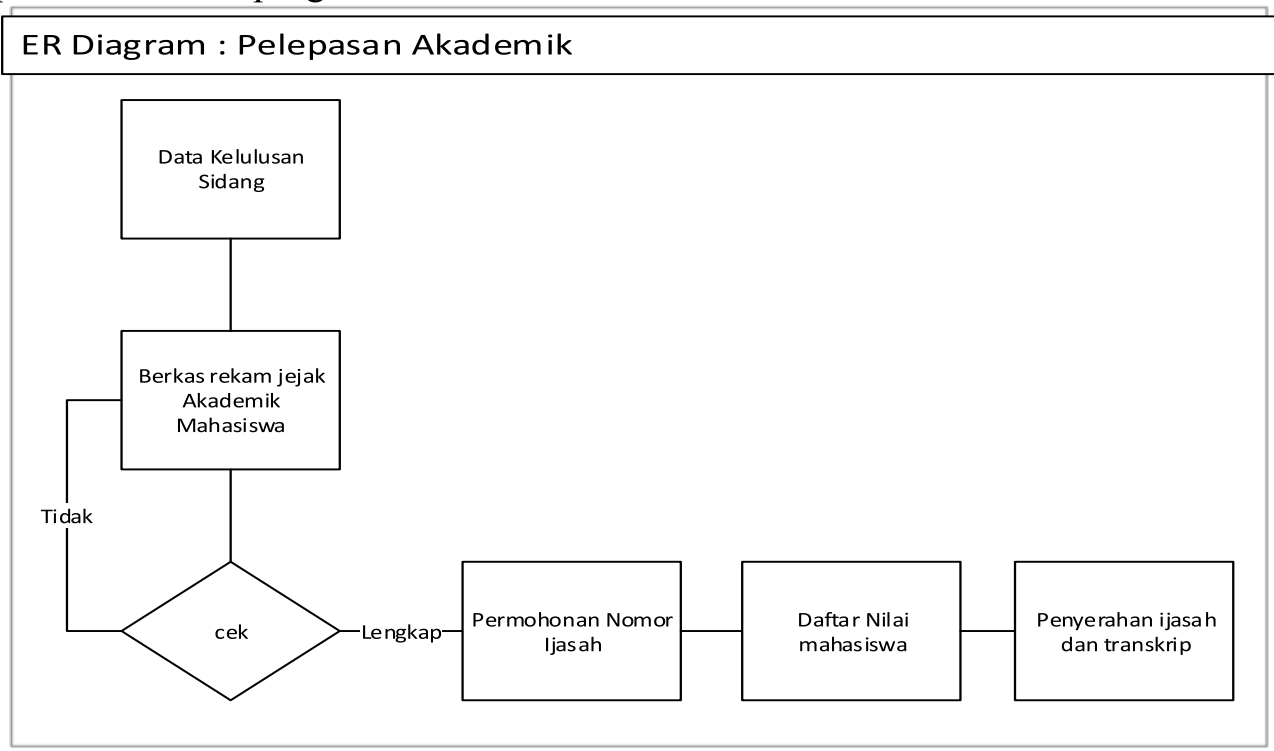

\section{Gambar 3.9}

ER Diagram Pelepasan Akademik

Gambar 3.9 menggambarkan diagram model arsitektur data untuk fungsi bisnis pelepasan akademik. Pada gambar tersebut digambarkan hubungan entitas data pada pelepasan akademik dimana entitas mahasiswa yang merupakan bagian dari program studi. Kemudian entitas alumni merupakan daftar mahasiswa yang telah lulus.

\subsection{Model Arsitektur Aplikasi}

Arsitektur aplikasi mempunyai tujuan untuk mendefinisikan aplikasi-aplikasi yang diperlukan untuk mengelola data dan mendukung fungsi-fungsi bisnis yang 
ada dalam Universitas Nahdlatul Ulama Cirebon. Model arsitektur aplikasi ini merupakan definisi tentang hal-hal yang dilakukan aplikasi untuk mengelola data dan menyediakan informasi bagi pelaksana fungsi-fungsi bisnis yang ada di Pergruan Tinggi. Arsitektur aplikasi dapat definisikan dengan teknik Application Portfolio Catalog dengan mendefinisikan daftar aplikasi yang dibutuhkan, berikut adalah kandidat aplikasi berdasarkan proses bisnis dengan entitas data yang terhubung pada tabel 3.2 berikut ini.

Tabel 3.2 Hubungan Fungsi dan kandidat aplikasi

\begin{tabular}{|c|c|c|}
\hline No & Fungsi Bisnis & Kandidat Aplikasi \\
\hline 1 & Penerimaan Mahasiswa Baru & $\begin{array}{l}\text { Penerimaan Mahasiswa Baru } \\
\text { Pendaftaran } \\
\text { Seleksi } \\
\text { Penerimaan Mahasiswa Baru }\end{array}$ \\
\hline 2 & Operasional Akademik & $\begin{array}{l}\text { Kegiatan Kademik } \\
\text { Perencanaan Akademik } \\
\text { Pendaftaran Ulang } \\
\text { Perkuliahan } \\
\text { Evaluasi } \\
\text { Cuti Akademik } \\
\text { Pelaporan Akademik }\end{array}$ \\
\hline 3 & Pelepasan Akademik & $\begin{array}{l}\text { Pelepasan Akademik } \\
\text { Administrasi Akademik } \\
\text { Wisuda } \\
\text { Pelaporan Pelepasan Akademik }\end{array}$ \\
\hline 4 & Penelitian dan Pengabdian & $\begin{array}{l}\text { Penelitian Pengabdian Masyarakat } \\
\text { Seleksi } \\
\text { Pelaporan P2M }\end{array}$ \\
\hline
\end{tabular}

\subsection{Model Arsitektur Teknologi}

Pada tahapan ini adalah membangun arsitektur teknologi yang diinginkan, dimulai dengan menentukan konsep dasar teknologi sampai alternatif teknologi yang diperlukan. Arsitektur teknologi ini mendefinisikan prinsip dasar teknologi yang akan digunakan untuk penyediaan lingkungan aplikasi dalam mengelola data dan sebagai alat dalam mendukung fungsi bisnis yang ada di Perguruan Tinggi. Arsitektur teknologi yang dihasilkan berupa konseptual sehingga bukan merupakan analisis kebutuhan secara detail melainkan hanya memberikan gambaran umum dan perlu ditinjau kembali saat melakukan implementasi.

Arsitektur teknologi informasi Perguruan Tinggi dibuat untuk mendefinisikan kebutuhan teknologi dalam mengolah data. Langkah awal yang akan dilakukan adalah dengan mendefinisikan kandidat teknologi yang akan digunakan berdasarkan prinsip dasar teknologi. Gambar 3.10 Menunjukkan prinsip dasar arsitektur teknologi informasi yang akan digunakan oleh Perguruan Tinggi 


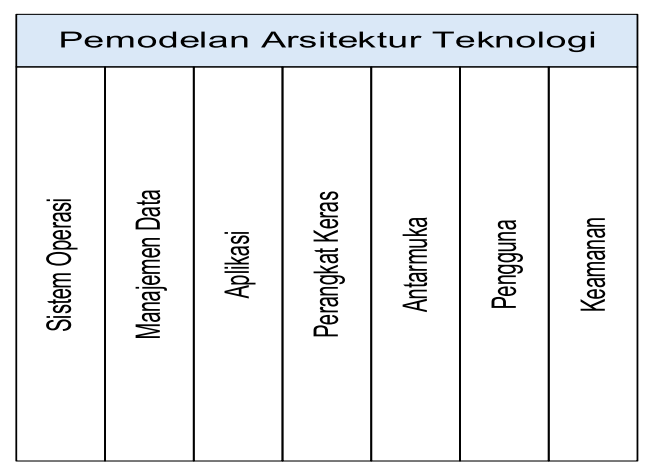

Gambar 3.10

Prinsip dasar arsitektur teknologi Perguruan Tinggi

Arsitektur teknologi yang akan digunakan mencakup sistem operasi yang akan digunakan oleh Perguruan Tinggi dapat menggunakan sistem operasi yang berbasis open source maupun sistem berlisensi. Manajeman data base yang akan digunakan dapat menggunakan MySQL atau oracle. Aplikasi berbasis web yang digunakan dapat menggunakan PHP . Perangkat keras yang akan digunakan meliputi perangkat server, perangkat jaringan Lokal/LAN pengguna dan perangkat pendukung lainnya. Antarmuka yang akan digunakan menggunakan service provider yang sesuai dengan kebutuhan. Sistem keamanan yang akan digunakan, keamanan jaringan, hak pakai penguna aplikasi dan jaringan (gambar 3.11)

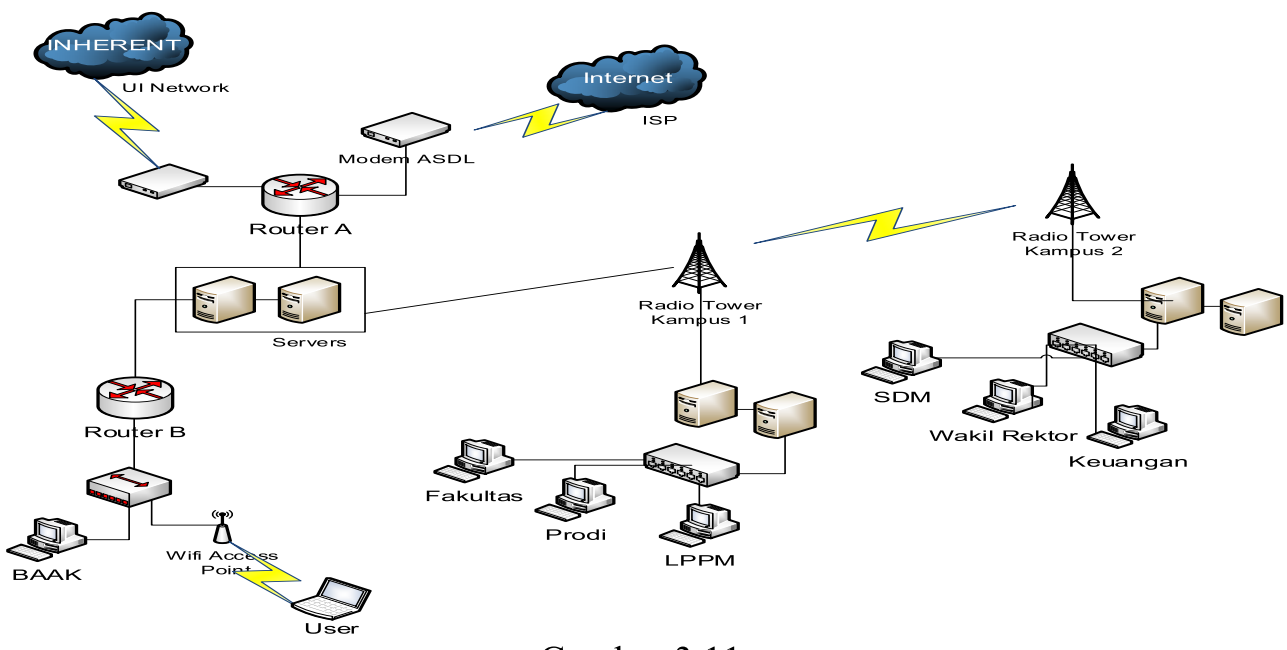

Gambar 3.11

Jaringan konseptual Perguruan Tinggi

\subsection{Rencana Implementasi}

Rencana implementasi merupakan bagian penting dalam EAP, di mana semua rencana aplikasi yang akan dibangun dapat diaplikasikan sesuai dengan waktu, biaya dan sesuai dengan kebutuhan organisasi. Untuk gambarannya rencana aplikasi dapat di lihat pada gambar 3.12 : 


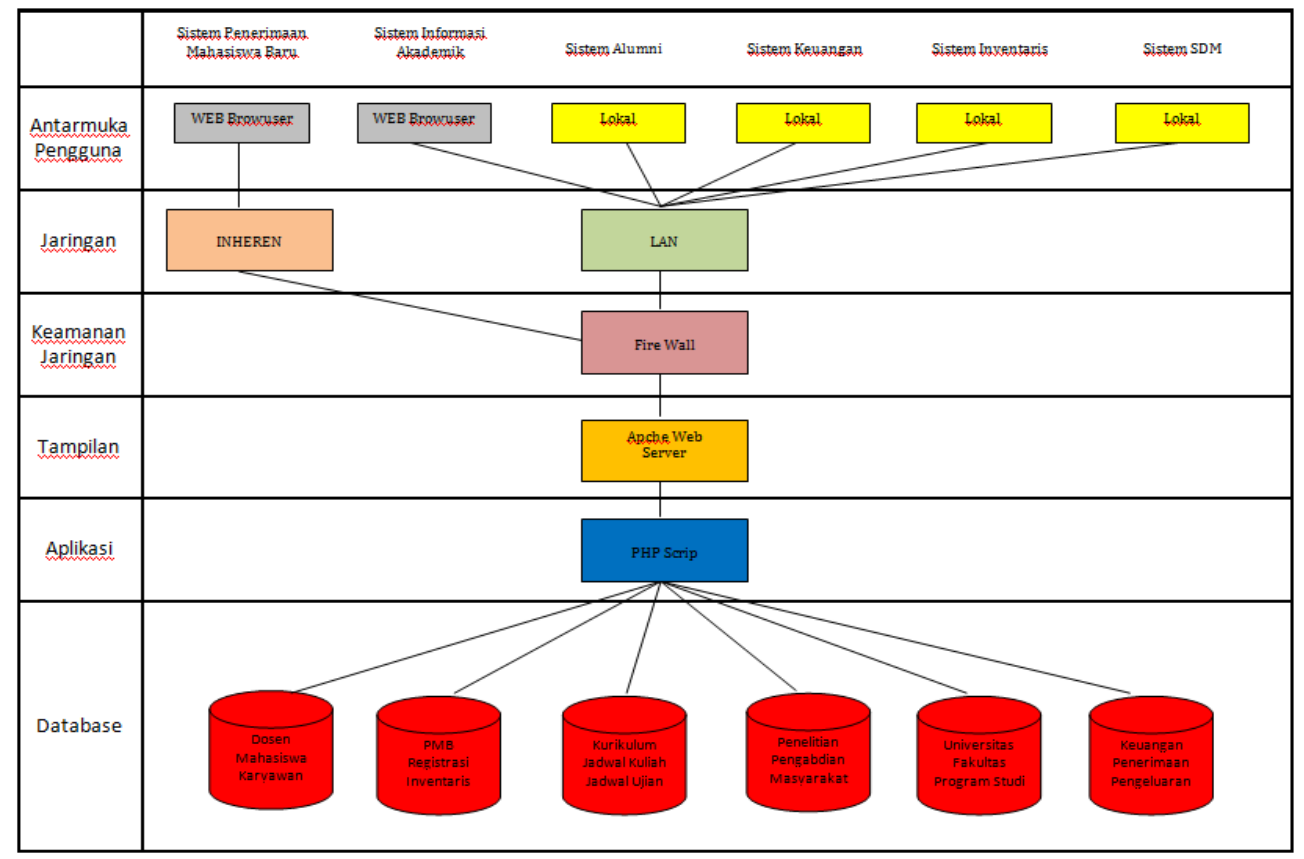

Gambar 3.12

Rencana Implementasi

\section{Kesimpulan}

Dari hasil penelitian perencanaan arsitektur sistem informasi Perguruan Tinggi dengan menggunakan metodologi enterprise architecture planning dapat diambil beberapa kesimpulan, antara lain :

1. Perencanaan arsitektur sistem informasi di Perguruan Tinggi, diperlukan untuk menjadi acuan yang baku dan dapat di jadikan sebagai dasar pemgembangan sistem informasi.

2. Manfaat perencanaan arsitektur sistem informasi di Perguruan Tinggi adalah sebagai landasan pengembangan sistem informasi, sehingga pengembangan yang dilakukan tidak keluar dari tujuan bisnis Perguruan Tinggi.

\section{Daftar Pustaka}

[1] Extended Enterprise Architecture Maturity Model Support Guide (Editorial Writer: J. Schekkerman, Version 2.0, 2006)

[2] Hariyanto Bambang "Sistem Manajemen Basisdata, Pemodelan, Perancangan dan Terapannya" Informatika, 2004

[3] IBM, Business System Planning (Information System Planning Guide), International Business Machines Corporation, 1981.

[4] Martin Owen and Jog Raj, BPMN and Business Process Management Introduction to the New Business Process Modeling Standard, (C) Popkin Software 2003 (www.popkin.com)

[5] Ladjamudin Bin Bahra Analisis dan Desain Sistem Informasi, Penerbit GRAHA ILMU Edisi Pertama 2005. 
[6] Laudon, K.C. dan Laudon, J.P. Sistem Informasi Manajemen: Mengelola Perusahaan Digital. Edisi Kedelapan. Diterjemahkan oleh Erwin Philippus. Yogyakarta: Andi,2004.

[7] Porter, Michael E, Competitive Advantage : Creating and Sustaining Superior Performance for Analyzing Industries and Competitor, The Free Press, 1985.

[8] Spewak, Steven H., Enterprise Architecture Planning (Developing a Blueprint for Data, Application and Technology), Jhon Wiley \& Sons,Inc.1992.

[9] Yunis, R. and Surendro, K., "Implementasi Enterprise Architecture Perguruan Tinggi”, Program Studi 